Background: DISCOVER-2 was a Phase 3 trial of the first-in-class anti-IL-23specific mAb guselkumab (GUS) in patients (pts) with psoriatic arthritis (PsA). PSA impacts patients' productivity at work and in daily activity. 1

Objectives: To evaluate the effect of GUS on work productivity and daily activity in DISCOVER-2 through 1 year using the Work Productivity and Activity Impairment Questionnaire: PsA (WPAl- PsA).

Methods: Bio-naïve adults with active PsA despite nonbiologic DMARDs \&/ or NSAIDs received subcutaneous GUS $100 \mathrm{mg}$ every 4 weeks (Q4W); GUS $100 \mathrm{mg}$ W0, W4, then Q8W; or placebo (PBO). At W24, PBO pts crossed over to GUS $100 \mathrm{mg}$ Q4W. WPAI-PsA assesses PsA-related work time missed (absenteeism), impairment while working (presenteeism), impaired overall work productivity (absenteeism + presenteeism), and daily activity during the previous week. A shift analysis evaluated proportions of pts employed vs unemployed (regardless of desire to work) over time. Among pts working at baseline, least-squares (LS) mean changes from baseline in WPAI-PsA domains were determined using a mixed-effects model for repeated measures analysis, whereby mean changes in WPAI-PsA domains were calculated for each multiple imputation (MI) dataset using an analysis of covariance (ANCOVA); the reported LSmean is the average of all MI datasets. Also, among pts employed at baseline, indirect savings from improved overall work productivity were estimated using 2020 EU mean yearly wage estimate (all occupations). 2

Results: In pts working at baseline, significant improvement in work productivity and non-work activity vs PBO was observed at W24. Productivity gains seen with GUS at W24 continued to improve through 1 year (Table 1). Shift analysis showed relatively stable employment in pts employed at baseline $(62 \%$ of shift analysis cohort) through 1 year of GUS (>91\% continued to work when assessed at W16, W24, and W52 [data not shown]). For those unemployed at baseline (38\% of cohort), the proportion of pts working increased by $\sim 10 \%$ following 1 year of GUS (Figure 1). Potential yearly indirect savings from improved overall work productivity were: $€ 7409$ GUS Q4W and $€ 7039$ GUS Q8W vs $€ 4075$ PBO at W24 and were €8520 GUS Q4W, €9632 GUS Q8W, and €6668 $\mathrm{PBO} \rightarrow$ GUS Q4W at W52.

Conclusion: Improvement in work productivity and non-work activity was greater with GUS vs PBO among pts with active PsA through W52. Improvements demonstrated may result in reduction in PsA costs associated with work productivity.

REFERENCES:

[1] Tillett W et al. Rheumatol (Oxford). 2012;51:275-83.

[2] OECD (2020). Average wages (indicator). https://data.oecd.org/earnwage/ average-wages.htm

Table 1. Model-based estimates of LSmean change ${ }^{a}(95 \% \mathrm{CI})$ from baseline in WPAI-PsA domains among pts working at baseline and with an observed change through W24 ( $=474)$ and W52 ( $=475)$

\begin{tabular}{|c|c|c|c|c|c|c|}
\hline \multirow{2}{*}{$\begin{array}{l}\text { Change from } \\
\text { baseline }\end{array}$} & \multicolumn{2}{|c|}{ GUS $100 \mathrm{mg}$ Q4W } & \multicolumn{2}{|c|}{ GUS $100 \mathrm{mg}$ Q8W } & \multirow{2}{*}{$\begin{array}{c}\begin{array}{c}\text { PBO } \\
\text { (W0-24) }\end{array} \\
\text { W24 }\end{array}$} & \multirow{2}{*}{$\begin{array}{c}\text { PBO } \rightarrow \\
\text { GUS } \\
100 \mathrm{mg} \\
\text { Q4W } \\
\text { (W24-52) } \\
\text { W52 }\end{array}$} \\
\hline & W24 & W52 & W24 & W52 & & \\
\hline Absenteeism, $\mathrm{N}$ & 145 & 145 & 147 & 147 & 162 & 163 \\
\hline LSmean & $\begin{array}{c}-3.4 \\
(-6.5,-0.3)\end{array}$ & $\begin{array}{c}-4.1 \\
(-6.8,-1.5)\end{array}$ & $\begin{array}{c}-3.0 \\
(-6.0,0.1)\end{array}$ & $\begin{array}{c}-4.0 \\
(-6.6,-1.3)\end{array}$ & $\begin{array}{c}-3.0(-6.0 \\
0.04)\end{array}$ & $\begin{array}{c}-3.0 \\
(-5.5,-0.4)\end{array}$ \\
\hline Diff vs. PBO & $\begin{array}{c}-0.4 \\
(-4.6,3.8)\end{array}$ & & $\begin{array}{c}-0.01(-4.2 \text {, } \\
4.2)\end{array}$ & & & \\
\hline $\begin{array}{l}\text { Presenteeism, N } \\
\text { LSmean }\end{array}$ & $\begin{array}{l}145 \\
-20.1\end{array}$ & $\begin{array}{c}145 \\
-22.4\end{array}$ & $\begin{array}{c}147 \\
-19.6\end{array}$ & $\begin{array}{c}147 \\
-25.7\end{array}$ & $\begin{array}{c}162 \\
-10.5\end{array}$ & $\begin{array}{c}163 \\
-18.5\end{array}$ \\
\hline & $(-23.7,-16.6)$ & $\begin{array}{c}(-26.3,- \\
18.6)\end{array}$ & $\begin{array}{c}(-23.2,- \\
16.1)\end{array}$ & $(-29.5,-21.8)$ & $(-13.9,-7.0)($ & $(-22.2,-14.7)$ \\
\hline Diff vs PBO & $\begin{array}{c}-9.7^{\star} \\
(-14.4,-5.0)\end{array}$ & & $\begin{array}{c}-9.2^{\star} \\
(-13.9,-4.5)\end{array}$ & & & \\
\hline $\begin{array}{l}\text { Work productivity, } \mathbf{N} \\
\text { LSmean }\end{array}$ & $\begin{array}{c}145 \\
-20.1\end{array}$ & $\begin{array}{c}145 \\
-22.6\end{array}$ & $\begin{array}{l}147 \\
-19.2\end{array}$ & $\begin{array}{c}147 \\
-25.9\end{array}$ & $\begin{array}{c}162 \\
-10.6\end{array}$ & $\begin{array}{c}163 \\
-17.6\end{array}$ \\
\hline & $(-24.1,-16.1)$ & $\begin{array}{c}(-26.8,- \\
18.3)\end{array}$ & $\begin{array}{c}(-23.1,- \\
15.2)\end{array}$ & $(-30.0,-21.7)$ & $(-14.4,-6.8)($ & $(-21.7,-13.6)$ \\
\hline Diff vs PBO & $\begin{array}{c}-9.5^{\star} \\
(-14.8,-4.2)\end{array}$ & & $\begin{array}{c}-8.6^{\star} \\
(-13.9,-3.3)\end{array}$ & & & \\
\hline Non-work Activity, N & 242 & 242 & 246 & 246 & 245 & 245 \\
\hline LSmean & -20.5 & -25.7 & -21.2 & -25.4 & -9.9 & -22.3 \\
\hline & $(-23.3,-17.7)$ & $\begin{array}{c}(-28.6,- \\
22.7)\end{array}$ & $\begin{array}{c}(-23.9,- \\
18.4)\end{array}$ & $(-28.4,-22.5$ & $(-12.6,-7.1)($ & $(-25.3,-19.4)$ \\
\hline Diff vs PBO & $\begin{array}{c}-10.6^{*} \\
(-14.4,-6.8)\end{array}$ & & $\begin{array}{c}-11.3^{\star} \\
(-15.1,-7.5)\end{array}$ & & & \\
\hline
\end{tabular}

$\mathrm{Cl}=$ Confidence interval

a. LSmean for each MI dataset is calculated based on an ANCOVA model for the change from baseline at W24/W52. The combined LSmean, which is the average of the LSmean, taken over all the MI datasets, is presented.

${ }^{*} \mathrm{p}<0.05$
Flgure. Shift Analysis of Working Status: Not Employed at Baseline

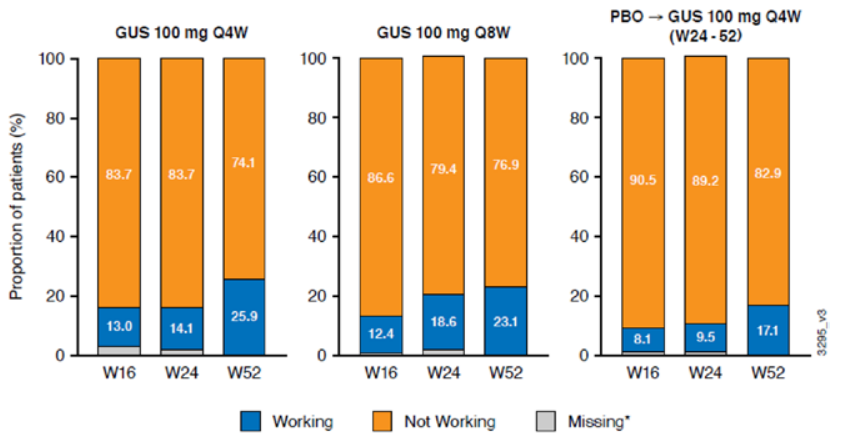

GUS $100 \mathrm{mg}$ O4W ( $(\mathrm{N}=92)$, GUS $100 \mathrm{mg}$ Q8W (N = 97), PBO $\rightarrow$ GUS $100 \mathrm{mg}$ Q4W (W24-52) $(\mathrm{N}=74)$

"GUS $100 \mathrm{mg}$ OAW: W16, 3.3\%; W24, 2.2\%, GUS $100 \mathrm{mg}$ O8W: W16, 1.0\%; W24, 2.1\%. PBO $\rightarrow$ GUS $100 \mathrm{mg}$ O4W (W24-52:

Disclosure of Interests: Jeffrey Curtis Consultant of: AbbVie, Amgen, Bristol-Myers Squibb, Corrona, Janssen, Lilly, Myriad, Pfizer, Regeneron, Roche, and UCB, Grant/research support from: AbbVie, Amgen, Bristol-Myers Squibb, Corrona, Janssen, Lilly, Myriad, Pfizer, Regeneron, Roche, and UCB, lain McInnes Consultant of: AbbVie, Bristol-Myers Squibb, Celgene, Eli Lilly and Company, Gilead, Janssen, Novartis, Pfizer, and UCB, Grant/research support from: Bristol-Myers Squibb, Celgene, Eli Lilly and Company, Janssen, and UCB, Steve Peterson Shareholder of: Johnson \& Johnson, Employee of: Janssen Global Services, LLC, Prasheen Agarwal Shareholder of: Johnson \& Johnson, Employee of: Janssen Research \& Development, LLC, Feifei Yang Shareholder of: Johnson \& Johnson, Employee of: Janssen Global Services, LLC, Alexa Kollmeier Shareholder of: Johnson \& Johnson, Employee of: Janssen Research \& Development LLC, Elizabeth C Hsia Shareholder of: Johnson \& Johnson, Employee of: Janssen Research \& Development, LLC, Chenglong Han Shareholder of: Johnson \& Johnson, Employee of: Janssen Research \& Development, LLC, William Tillett Speakers bureau: AbbVie, Amgen, Celgene, Lilly, Janssen, Novartis, Pfizer Inc, and UCB, Consultant of: AbbVie, Amgen, Celgene, Lilly, Janssen, Novartis, MSD, Pfizer Inc, and UCB, Grant/research support from: AbbVie, Celgene, El Lilly, Janssen, Novartis, Pfizer Inc, and UCB, Philip J Mease Speakers bureau: Boehringer Ingelheim and GlaxoSmithKline, Grant/research support from: AbbVie, Amgen, Bristol Myers Squibb, Eli Lilly, Galapagos, Gilead, Janssen, Novartis, Pfizer, SUN, and UCB, Proton Rahman Speakers bureau: AbbVie, Eli Lilly, Janssen, Novartis, Pfizer, and UCB, Consultant of: AbbVie, Amgen, Bristol Myers Squibb, Celgene, Eli Lilly, Janssen, Novartis, Pfizer, Roche, and UCB, Grant/ research support from: Janssen and Novartis.

DOI: 10.1136/annrheumdis-2021-eular.244

\section{POS1027 EFFICACY AND SAFETY OF GUSELKUMAB, A MONOCLONAL ANTIBODY SPECIFIC TO THE P19- SUBUNIT OF INTERLEUKIN-23, THROUGH 2 YEARS: RESULTS FROM A PHASE 3, RANDOMIZED, DOUBLE- BLIND, PLACEBO-CONTROLLED STUDY CONDUCTED IN BIOLOGIC-NAÏVE PATIENTS WITH ACTIVE PSORIATIC ARTHRITIS}

I. Mcinnes ${ }^{1}$, P. Rahman ${ }^{2}$, A. B. Gottlieb ${ }^{3}$, E. C. Hsia $^{4,5}$, A. Kollmeier ${ }^{4}$, X. L. Xu ${ }^{4}$, S. Sheng ${ }^{6}$, Y. Jiang ${ }^{6}$, M. Shawi ${ }^{7}$, S. D. Chakravarty ${ }^{8,9}$, D. Van der Heijde ${ }^{10}$, P. J. Mease ${ }^{11}$. ${ }^{1}$ University of Glasgow, Institute of Infection, Immunity and Inflammation, Glasgow, United Kingdom; ${ }^{2}$ Memorial University of Newfoundland, Craig L Dobbin Genetics Research Centre, St. John's, Canada; ${ }^{3}$ Icahn School of Medicine Mt. Sinai, Dermatology, New York, United States of America; ${ }^{4}$ Janssen Research \& Development, LLC, Immunology, Spring House, United States of America; ${ }^{5}$ University of Pennsylvania Medical Center, Rheumatology, Philadelphia, United States of America; 6 Janssen Research \& Development, LLC, Biostatistics, Spring House, United States of America:

${ }^{7}$ Janssen Scientific Affairs, LLC, Immunology, Horsham, United States of America; ${ }^{8}$ Janssen Scientific Affairs, LLC, Immunology, Horsham, United States of America; ${ }^{9}$ Drexel University College of Medicine, Rheumatology, Philadelphia, United States of America; ${ }^{10}$ Leiden University Medical Center, Rheumatology, Leiden, Netherlands; ${ }^{11}$ Swedish Medical Center/Providence St. Joseph Health and University of Washington, Rheumatology Research, Seattle, United States of America

Background: Guselkumab (GUS), a selective IL-23 inhibitor dosed every 4 or 8 weeks (Q4W or Q8W), demonstrated efficacy for joint and skin symptoms, inhibition of structural damage progression (Q4W), and safety vs. placebo (PBO) through Week 24 (W24) of the Ph3, double-blind, PBO-controlled trial in biologic-naïve pts with PsA (DISCOVER-2). ${ }^{1}$ Favorable benefit-risk was also seen through 1 year. $^{2}$

Objectives: To assess GUS efficacy and safety through 2 years. 
Methods: Biologic-naïve adults with active PsA ( $\geq 5$ swollen joint count [SJC] + $\geq 5$ tender joint count [TJC]; CRP $\geq 0.6 \mathrm{mg} / \mathrm{dL})$ were randomized $(1: 1: 1)$ to GUS $100 \mathrm{mg}$ Q4W; GUS $100 \mathrm{mg}$ at W0, W4, Q8W; or PBO with crossover to GUS $100 \mathrm{mg}$ Q4W (PBO $\rightarrow$ Q4W) at W24. Clinical efficacy (ACR/PASI/IGA/HAQ-DI) was assessed in the modified intention to treat (mITT) population through W100 with missing data imputation (nonresponse for categorical endpoints; no change/ multiple imputation for continuous endpoints). Observed PsA-modified van der Heijde Sharp (vdH-S) scores derived from blinded radiographic images collected at W0, W24, W52, W100 (or at discontinuation [d/c]) and adverse events (AEs) through W112 were collected.

Results: 712/739 (96\%) randomized pts continued study agent at W24; 687/739 (93\%) continued at W52; 652/739 (88\%) completed W100. ACR20 response rates in the mITT population continued to increase after W24, and at W100 were $76 \%$ for Q4W and 74\% for Q8W (Figure 1). Similar response patterns were seen for ACR50/70, HAQ-DI and PASI90/100 (Table 1), and IGA0/1 and PASI75 response rates were consistent through W100 in pts randomized to $\mathrm{Q} 4 \mathrm{~W}$ and $\mathrm{Q} 8 \mathrm{~W} ; \mathrm{W} 100$ data for PBO $\rightarrow$ Q4W pts were consistent with pts treated with Q4W and Q8W (Table 1). GUS improvements in SF-36 PCS/MCS at W52 also persisted through W100 (data not shown). Low rates of radiographic progression (as measured by PsA-modified vdH-S scores) were observed during W52-100 for Q4W ( $n=227 ; 0.75)$ and Q8W $(n=232 ; 0.46)$. In the $P B O \rightarrow Q 4 W$ group $(n=228)$, radiographic progression was 1.12 during W0-24 (while on PBO), 0.51 during W24-100 (while on Q4W), and 0.13 during W52-100. Through W112, the incidences of AEs, serious AEs (SAEs), AEs leading to $\mathrm{d} / \mathrm{c}$, infections, serious infections, and injection site reactions were generally consistent with the PBO-controlled period and through 1 year. Of the pts in the Q4W $(\mathrm{n}=245), \mathrm{Q} 8 \mathrm{~W}(\mathrm{n}=248)$, and $\mathrm{PBO} \rightarrow \mathrm{Q} 4 \mathrm{~W}(\mathrm{n}=238)$ groups, $9 \%, 9 \%$ and $7 \%$ had $\geq 1$ $\mathrm{SAE} ; 2 \%, 3 \%$ and $3 \%$ had $\geq 1$ serious infection; 2 Q $8 \mathrm{~W}$ pts (fungal esophagitis, disseminated herpes zoster) and $1 \mathrm{PBO} \rightarrow \mathrm{Q} 4 \mathrm{~W}$ pt (listeria meningitis) had opportunistic infections; $1 \mathrm{PBO} \rightarrow \mathrm{Q} 4 \mathrm{~W}$ pt died (road traffic accident); 1 PBO-randomized pt had IBD; no pt had anaphylactic or serum sickness reaction, or active TB.

Conclusion: In biologic-naïve PsA pts, GUS improvements in joint and skin symptoms, physical function, and low rates of radiographic progression persisted through 2 years. GUS safety in PsA through 2 years was comparable with safety at 6 months and 1 year, similar between Q4W and Q8W, and consistent with GUS safety in psoriasis.

REFERENCES:

[1] Mease PJ. Lancet. 2020 Apr 4;395(10230):1126-1136. [2] Mclnnes IB. Arthritis Rheumatol. 2020 Oct 11. doi: 10.1002/art.41553.

Table 1. Efficacy Through W100 (NRI)

\begin{tabular}{|c|c|c|c|c|c|c|c|c|c|}
\hline \multirow[t]{2}{*}{ Data are \% } & \multicolumn{3}{|c|}{ GUS Q4W } & \multicolumn{3}{|c|}{ GUS Q8W } & \multicolumn{3}{|c|}{ PBO $\rightarrow$ GUS Q4W } \\
\hline & W24 & W52 & W100 & W24 & W52 & W100 & W24 & W52 & W100 \\
\hline Analysis set, $\mathrm{n}$ & & 245 & & & 248 & & & 246 & \\
\hline ACR 50 & 33 & 46 & 56 & 32 & 48 & 55 & 14 & 41 & 48 \\
\hline ACR 70 & 13 & 26 & 35 & 19 & 28 & 36 & 4 & 18 & 30 \\
\hline BL HAQ-DI $\geq 0.35, n$ & & 228 & & & 228 & & & 236 & \\
\hline Improvement $\geq 0.35^{\mathrm{a}}$ & 56 & 59 & 63 & 50 & 58 & 64 & 31 & 48 & 56 \\
\hline $\mathrm{BL} \geq 3 \%$ BSA psoriasis $+\mathrm{IGA} \geq 2, n$ & & 184 & & & 176 & & & 183 & \\
\hline IGA0/1 & 69 & 63 & 62 & 71 & 58 & 55 & 19 & 63 & 67 \\
\hline PASI75 & 78 & 87 & 83 & 79 & 86 & 82 & 23 & 83 & 80 \\
\hline PASI90 & 61 & 77 & 74 & 69 & 74 & 70 & 10 & 72 & 77 \\
\hline PASI100 & 45 & 58 & 59 & 45 & 53 & 53 & 3 & 52 & 61 \\
\hline
\end{tabular}

BL, Baseline; BSA, Body surface area; HAQ-DI, Health assessment questionnaire disability index; IGA, Investigator global assessment; NRI, nonresponder imputation; PASI, Psoriasis area and severity index. ${ }^{a} \geq 0.35$ improvement among pts with $\mathrm{HAQ}-\mathrm{DI} \geq 0.35$ at $\mathrm{BL}$.

Flgure. ACR 20 Response Through W100 (NRI) (Note: Patients randomized to PBO crossed over to GUS $100 \mathrm{mg}$ Q4W at W24)

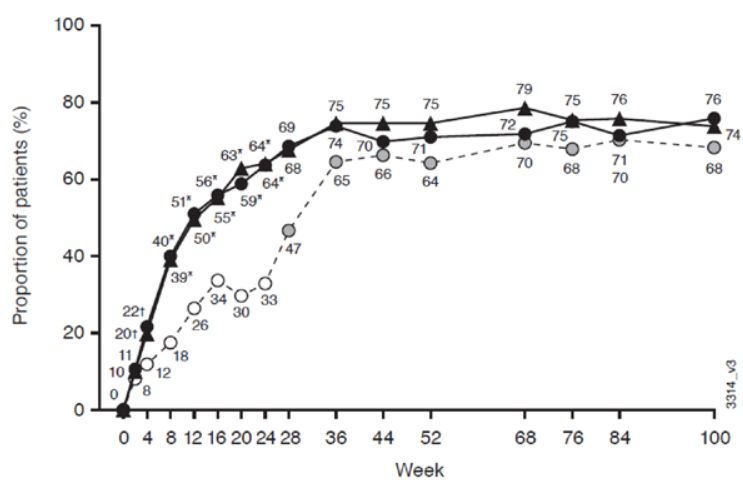

Disclosure of Interests: lain Mclnnes Consultant of: AbbVie, Bristol-Myers Squibb, Celgene, Eli Lilly and Company, Gilead, Janssen, Novartis, Pfizer, and
UCB, Grant/research support from: Bristol-Myers Squibb, Celgene, Eli Lilly and Company, Janssen, and UCB, Proton Rahman Speakers bureau: AbbVie, Eli Lilly, Janssen, Novartis, Pfizer, and UCB, Consultant of: AbbVie, Amgen, Bristo Myers Squibb, Celgene, Eli Lilly, Janssen, Novartis, Pfizer, Roche, and UCB, Grant/research support from: Janssen and Novartis, Alice B Gottlieb Consultant of: Avotres Therapeutics, Beiersdorf, Boehringer Ingelheim, Bristol-Myers Squibb Co, Incyte, Janssen, LEO Pharma, Eli Lilly, Novartis, Sun Pharmaceutical Industries Inc, UCB, and Xbiotech, Grant/research support from: Boehringer Ingelheim, Incyte, Janssen, Novartis, Sun Pharmaceuticals Industries Inc, UCB, and Xbiotech, Elizabeth C Hsia Shareholder of: Johnson \& Johnson, Employee of: Janssen Research and Development, LLC, Alexa Kollmeier Shareholder of: Johnson \& Johnson, Employee of: Janssen Research \& Development, LLC, Xie L Xu Shareholder of: Johnson \& Johnson, Employee of: Janssen Research \& Development, LLC, Shihong Sheng Shareholder of: Johnson \& Johnson, Employee of: Janssen Research \& Development, LLC, Yusang Jiang Employee of: Cytel, Inc. providing statistical support (funded by Janssen), May Shawi Shareholder of: Johnson \& Johnson, Employee of: Janssen Scientific Affairs, LLC, Soumya D Chakravarty Shareholder of: Johnson \& Johnson, Employee of: Janssen Scientific Affairs, LLC, Désirée van der Heijde Paid instructor for: Director of Imaging and Rheumatology BV, Consultant of: AbbVie, Amgen, Astellas, AstraZeneca, Bayer BMS, Boehringer Ingelheim, Celgene, Cyxone, Daiichi, Eisai, Eli Lilly, Galapagos, Gilead, GlaxoSmithKline, Janssen, Merck, Novartis, Pfizer, Regeneron, Roche Sanofi, Takeda, and UCB, Philip J Mease Speakers bureau: Boehringer Ingelheim and GlaxoSmithKline, Grant/research support from: AbbVie, Amgen, Bristol Myers Squibb, Eli Lilly, Galapagos, Gilead, Janssen, Novartis, Pfizer, SUN, and UCB. DOI: 10.1136/annrheumdis-2021-eular.409

\section{POS1028 \\ PATIENT CHARACTERISTICS \& CLINICAL FEATURES ASSOCIATE WITH HEALTH-RELATED QUALITY OF LIFE IN BIO-NAÏVE PATIENTS WITH ACTIVE PSORIATIC ARTHRITIS THROUGH WEEK 24 OF THE DISCOVER-2 STUDY}

J. Curtis $^{1}$, I. Mcinnes ${ }^{2}$, D. D. Gladman ${ }^{3}$, F. Yang ${ }^{4}$, S. Peterson ${ }^{4}$, P. Agarwal ${ }^{5}$, A. Kollmeier ${ }^{6}$, E. C. Hsia ${ }^{6,7}$, C. $\mathrm{Han}^{6}$, M. Shawi ${ }^{4}$, W. Tillett ${ }^{8}$, P. J. Mease ${ }^{9}$, P. Rahman ${ }^{10} .{ }^{1}$ University of Alabama at Birmingham, Department of Medicine, Immunology and Rheumatology, Birmingham, United States of America; ${ }^{2}$ University of Glasgow, Institute of Infection, Immunity and Inflammation, Rheumatology, United Kingdom; ${ }^{3}$ Centre for Prognosis in the Rheumatic Diseases, Toronto Western Hospital, Professor of Medicine, Toronto, Canada; ${ }^{4}$ Janssen Global Services, LLC, Immunology, Horsham, United States of America; ${ }^{5}$ Janssen Research \& Development, LLC, Biostatistics, Spring House, United States of America; ${ }^{6}$ Janssen Research \& Development, LLC, Immunology, Spring House, United States of America; ${ }^{7}$ University of Pennsylvania Medical Center, Rheumatology, Philadelphia, United States of America; ${ }^{8}$ Royal National Hospital for Rheumatic Diseases, Department of Pharmacy \& Pharmacology Centre for Therapeutic Innovation, Bath, United Kingdom; ${ }^{9}$ Swedish Medical Center/Providence St. Joseph Health and University of Washington, Rheumatology Research, Seattle, United States of America; ${ }^{10}$ Memorial University of Newfoundland, Craig L Dobbin Genetics Research Centre, St. John's, Canada

Background: Psoriatic arthritis (PsA) is a chronic inflammatory disease characterized by peripheral arthritis, axial inflammation, dactylitis, enthesitis, \& skin/nail psoriasis. Patients (pts) with PsA often experience reduced health-related quality of life (HRQoL) due to these features.

Objectives: Using EuroQoL-5 dimension-5 level (EQ-5D-5L) questionnaire index \& visual analog scale (EQ-VAS) scores, we assessed HRQoL in pts with PSA \& its association with pt characteristics \& clinical features of PsA, including fatigue. Methods: The Phase 3 DISCOVER-2 trial evaluated guselkumab (GUS), a human monoclonal antibody targeting the IL-23p19-subunit, in bio-naïve adults with active PsA (swollen joint count [SJC] $\geq 5$, tender joint count $[\mathrm{TJC}] \geq 5$, C-reactive protein $[\mathrm{CRP}] \geq 0.6 \mathrm{mg} / \mathrm{dL}$ ) despite standard therapies. ${ }^{1} \mathrm{Pts}$ were randomized 1:1:1 to GUS $100 \mathrm{mg}$ every 4 weeks (Q4W); GUS $100 \mathrm{mg}$ at Week 0 (W0), W4, then Q8W; or placebo (PBO). EQ-5D-5L index assesses mobility, self-care, usua activities, pain/discomfort, \& anxiety/depression. EQ-VAS assesses pt health state. Spearman correlation testing was used to evaluate relationships between baseline (BL) pt characteristics \& PsA clinical features \& BL EQ-5D-5L index \& EQ-VAS scores (Figure 1). Employing absolute observed scores at both W0 \& W24, univariate linear regression was used to assess the association between EQ-5D-5L index \& EQ-VAS scores \& pt characteristics/PsA clinical features. Variables with $p<0.20$ in the univariate analysis were included in a multivariate analysis employing mixed-effect model for repeated measures (MMRM), controlling for all other variables; resulting $p$ values $<0.05$ were considered statistically significant. Least-squares (LS) mean changes in EQ-5D-5L index \& EQ-VAS were assessed at W24 using MMRM.

Results: Among 738 pts, BL EQ-5D-5L index \& EQ-VAS scores were moderately to strongly correlated (ie, $\geq 0.4$ ) with $\mathrm{BL}$ pt-reported pain (0-10 VAS), physical function (Health Assessment Questionnaire-Disability Index [HAQ-DI]) 